\title{
MEKANISME DAN MASALAH PEMBIAYAAN MUDHARABAH PADA KANTOR BANK PANIN DUBAI SYARIAH CABANG MAKASSAR
}

\author{
Ismawati \\ Universitas Islam Negeri Alauddin Makassar \\ ismawatiabbas77@gmail.com
}

\begin{abstract}
Keywords:
ABSTRACT

Mudharabah, profit and loss sharing, Panin Dubai Syariah Bank

Kata Kunci:

The fact that of all the financing available at Panin Dubai Sharia Bank Makassar, Mudharabah financing is the slowest product in the last 5 (five) years. In this article, the focus on Islamic banks' panin products is in line with the spirit of creating a fair profit and loss sharing system in Mudharabah products. The approach used in the research is descriptive qualitative. This approach is used to uncover mechanisms and problems in Mudharabah Financing at Panin Dubai Bank in Makassar. Mudharabah financing constraints are more than the Panin Dubai Syariah Makassar policy which sets high tariffs on Mudharabah financing which makes the range of Mudharabah financing to be among the big entrepreneurs only. Therefore, many people are not touched by Mudharabah financing. The procedure determined by Panin Dubai Syariah Makassar Bank will make it difficult for customers to submit new customers who will start their business activities. Because new entrepreneurs or MSMEs cannot meet the requirements of the requirements set out in the financing procedure. There are also strict rules from the OJK that only sharia business units may be given financing.
\end{abstract}

Mudharabah, Bagi

Hasil, Bank Panin Dubai Syariah.

\begin{tabular}{l} 
ABSTRAK \\
\hline Kenyataan bahwa dari semua pembiayaan yang ada di Bank Panin \\
Dubai Syariah Makassar terlihat pembiayaan Mudharabah merupakan \\
produk yang paling lambat perkembangannya dalam periode 5 (lima) \\
tahun terakhir.Dalam artikel ini difokuskan pada produk panin bank \\
syariah yang sejalan dengan semangat mewujudkan sistem bagi hasil \\
(profit and loss sharing) yang adil dalam produk Mudharabah. Pendekatan \\
yang digunakan dalam penelitian ini adalah pendekatan deskriptif. \\
Pendekatan ini digunakan untuk mengungkap mekanisme dan \\
masalah dalam Pembiayaan Mudharabah di Bank Panin Dubai \\
Makassar. Kendala pembiayaan Mudharabah lebih kepada dari \\
kebijakan Bank Panin Dubai Syariah Makassar yang menetapkan tarif \\
tinggi pada pembiayaan Mudharabah yang membuat jangkauan dari \\
pembiayaan Mudharabah menjadi pada kalangan pengusaha besar saja. \\
Oleh sebab itu banyak masyarakat yang tidak tersentuh oleh \\
pembiayaan Mudharabah. Prosedur yang ditentukan oleh Bank Panin \\
Dubai Syariah Makassar akan menyulitkan nasabah untuk melakukan \\
pengajuan nasabah yang baru akan memulai kegiatan usahannya. \\
Karena para pengusaha baru atau UMKM tidak bisa memenuhi \\
persyaratan persyaratan yang ditetapkan dalam prosedur pembiayaan. \\
Jugaadanya aturan yang ketat dari OJK bahwa hanya unit usaha \\
syariah yang boleh diberikan pembiayaan.
\end{tabular}

\section{PENDAHULUAN}

Perbankan syariah adalah suatu sistem perbankan berdasarkan syariat Islam. Usaha pembentukan sistem ini didasari oleh larangan dalam agama Islam untuk memungut maupun 
Ismawati. Mekanisme dan Masalah Pembiayaan Mudharabah...

meminjam dengan bunga atau yang disebut dengan riba. Perbankan syariah memberikan layanan bebas bunga kepada para nasabahnya.Pembayaran dan penarikan bunga dilarang dalam semua bentuk transaksi. Pelarangan ini salah satu yang membedakan sistem perbankan syariah dengan perbankan konvensional.

Bank syariah juga memiliki produk-produk yang bergerak dibidang penyaluran dana atau pembiayaan. Produk-produk yang lazim digunakan oleh Bank syariah adalah: Mudharabah, Musyarakah, Murabahah, Ijarah, dan sebagainya. Dari sudut pandang kepentingan ekonomi, pembiayaan perbankan syariah yang menggunakan sistem Mudharabah (profit and losssharing) dalam memperlancar roda perekonomian umat dianggap mampu menekan terjadinya inflasi karena tidak adanya ketetapan bunga yang harus dibayarkan ke bank, (Agutianto, 2012).

Pembiayaan Mudharabah secara tidak langsung adalah bentuk penolakan terhadap sistem bunga yang diterapkan oleh bank konvensional dalam mencari keuntungan. Karena itu pelarangan bunga ditinjau dari ajaran Islam merupakan perbuatan riba yang diharamkan dalam Al-qur'an, sebab larangan riba tersebut bukanlah meringankan beban orang yang dibantu dalam hal ini nasabah/mudharib tetapi merupakan tindakan yang memperalat dan memakan harta orang lain tanpa melalui jerih payah dan berisiko serta kemudahan yang diperoleh orang kaya di atas kesedihan orang miskin, (Qordhawi, 1997).

Dengan demikian perbankan syariah yang memberikan pembiayaan Mudharabah terhadap nasabah/mudharib dengan sendirinya akan menjadikan hubungan di antara kedua belah pihak bagaikan mitra dalam meraih keuntungan riil pada pengelolaan kegiatan usaha mereka. Pada konsep pembiayaan bagi hasil Mudharabah dalam perbankan syariah dikenal dengan istilah Qiradh adalah akad kerja sama antara dua pihak dimana pemilik dana (ShabibulMal) menyediakan seluruh modal sedangkan pihak kedua (Mudharib) bertindak selaku pengelola dan keuntungan usaha di bagi di antara mereka sesuai dengan kesepakatan yang dituangkan dalam kontrak, (DSN-MUI, 2000).

Akad Mudharabah yang dilakukan antara bank dengan pemilik tabungan Mudharabah dan deposito Mudharabah membawa konsekuensi resiko bagi pemilik dana akan kemungkinan ruginya usaha bank. Namun resiko ini relatif lebih ringan karena ketatnya pengawasan Bank Sentral kepada sektor perbankan. Selain itu sektor perbankan diwajibkan mengikuti berbagai ketentuan Pemerintah dan Bank Sentral dalam rangka melindungi pemilik dana.Disisi lain pada waktu bank bertindak sebagai pemilik dana (Shahibual-Mal), bank mengahadapi risiko yang lebih besar karena belum adanya standar biaya untuk berbagai jenis usaha yang berbeda. Standar biaya yang berlaku sekarang hanya menyangkut "upah minimum regional" sedang untuk biaya operasional lainnya belum ada.Selain itu, tidak ada lembaga yang membina dan mengawasi nasabah yang berperansebagai Mudharib.

Dengan demikian dibandingkan dengan usaha bank dalam bentuk pembiayaan perdagangan (jual-beli) melalui akad Murabaha, Bai Bithaman Ajil, Salam, Ijarah, Istishna',dan derivatifnya, usaha pembiayaan dalam bentuk penyertaan modal dianggap lebih besar risikonya terutama pada akad Mudharabah. Karena pada akad Mudharabah ini, pihak bank menyediakan 100 persen kebutuhan modal usaha sedang pihak pengusaha menyediakan jasa pengelolaan usaha. Sebagai Shabibu Al-Mal, bank tidak dibolehkan turut campur dalam kegiatan sehari-hari pihak pengelola usaha. Hasil yang diperoleh dari usaha yang dikelola dibagihasilkan antara bank dengan pengelola usaha sesuai dengan porsi yang disepakati bersama.

Dalam hal terjadi kerugian, maka rugi uang ditanggung seluruhnya atau sebagian oleh bank, sedang pengelola tidak memperoleh bayaran dari usahanya. Tingginya resiko (bigh risk) inilah yang menjadikan mengapa komposisi penyaluran dana kepada masyarakat yang lebih banyak dalam bentuk pembiayaan perdagangan (Murababab), dibandingkan dengan bentuk penyertaan modal (Mudharabah dan Musyarakah), padahal yang mempunyai dampak langsung kepada pertumbuhan ekonomi berupa tumbuhnya peluang usaha baru, kesempatan kerja baru, dan peningkatan pendapatan penduduk adalah pembiayaan dalam bentuk kerjasama ini baik 
AL-MASHRAFIYAH: Jurnal Ekonomi, Keuangan, dan Perbankan Syariah Volume 2, Nomor 2, Oktober 2018

Mudharabah maupun Musyarakah.

Pembiayaan bagi hasil adalah pola pembiayaan yang mencerminkan spirit perbankan syariah, dengan alasan adalah sebagai berikut; pertama, pembiayaan bagi hasil dapat mengurangi peluang terjadinya resesi ekonomi dan krisis keuangan. Hal ini dikarenakan bank syariah adalah institusi keuangan yang berbasis asset (asset-based). Artinya, bank syariah bertransaksi berdasarkan asset riil dan bukan mengandalkan pada kertas kerja semata. Sementara disisi lain, bank konvensional hanya bertransaksi berdasarkan Paper Work, dan dokumen semata, kemudian membebankan bunga dengan prosentase tertentu kepada calon investor. Kedua, investasi akan meningkat yang disertai dengan pembukaan lapangan kerja baru. Akibatnya tingkat pengangguran akan dapat dikurangi dan pendapatan masyarakat akan bertambah. Ketiga, pembiayaan bagi hasil akan mendorong tumbuhnya pengusaha atau investor yang berani mengambil keputusan bisnis yang beresiko. Hal ini akan menyebabkan berkembangnya berbagai inovasi baru, yang pada akhirnya dapat meningkatkan daya saing bangsa ini.Bila ditinjau dari sisi nasabah, nasabah akan membandingkan secara cermat antara expected rate of return yang ditawarkan oleh bank syariah dengan tingkat suku bunga yang ditawarkan oleh bank konvensional.

Dari uraian diatas terlihat bahwa skim pembiayaan yang tepat sebagai mesin akselerasi pembangunan kesejahteraan ekonomi masyarakat adalah pembiayaan Mudharabah (bagi hasil), yang tentuya harus dilaksanakan secara professional, serta dengan pengawasan yang ketat dari bank sentral dan otoritas jasa keuangan.

Masalah dalam paper ini difokuskan pada produk panin bank syariah yang sejalan dengan semangat mewujudkan sistem bagi hasil (profit and loss sharing) yang adil dalam produk Mudharabah. Selaras dengan perkembangan pembiayaan pada bank syariah secara keselurahan terlihat pula kenyataan bahwa dari semua pembiayaan yang ada di Bank Panin Dubai Makassar terlihat pembiayaan Mudharabah merupakan produk yang paling lambat perkembangannya dalam periode 5 (lima)tahun terakhir.

\section{LANDASAN TEORI}

Mudharabah berasal dari kata dharb, yang berarti memukul atau berjalan. Pengertian memukul atau berjalan ini lebih tepatnya adalah proses seseorang memukulkan kakinya dalam menjalankan usaha. Secara teknis, al-Mudharabah adalah akad kerjasama usaha antara dua pihak dimana pihak pertama (shabibul mal) menyediakan seluruh (100\%) modal, sedangkan pihak lainnya menjadi pengelola.

Mudharabah berdasarkan ahli fiqih merupakan suatu perjanjian dimana seseorang memberi hartanya kepada orang lain berdasarkan prinsip dagang. Keuntungan yang diperoleh akan dibagi berdasarkan proporsi yang telah disetujui,seperti $1 / 2$ dari keuntungan atau $1 / 4$ dan sebagainya.

Menurut istilah, Mudharabah atau qiriadh dikemukakan oleh para ulama sebagai berikut:

1. Menurut para fuqaha, Mudharabah ialah akad antara dua pihak (orang) saling menanggung, salah satu pihak menyerahkan hartanya kepada pihak lain untuk diperdagangkan dengan bagian yang telah ditentukan dari keuntungan, seperti setengah atau sepertiga dengan syarat-syarat yang telah ditentukan.

2. Ulama Syafi iyah berpendapat bahwa Mudharabah ialah akad yang menentukan seseorang menyerahkan hartanya kepada yang lain untuk ditijarahkan.

3. Sayyid Sabiq berpendapat, Mudharabah ialah akad antara dua belah pihak untuk salah satu pihak mengeluarkan sejumlah uang untuk diperdagangkan dengan syarat keuntungan dibagi dua sesuai dengan perjanjian.

Mudharabah merupakan kontrak yang melibatkan antara dua kelompok, yaitu pemilik modal (investor) yang mempercayakan modalnya kepada pengelola (mudharib) untuk digunakan 
Ismawati. Mekanisme dan Masalah Pembiayaan Mudharabah...

dalam aktivitas perdagangan. Mudharib dalam hal ini memberikan kontribusi pekerjaan, waktu, dan mengelola usahanya sesuai dengan ketentuan yang dicapai dalam kontrak, salah satunya adalah untuk mencapai keuntungan (profit) yang dibagi antara pihak investor dan mudharib berdasarkan proporsi yang telah disetujui bersama.

Menurut PSAK No.105 Mudharabah adalah akad kerja sama antara dua pihak dimana pihak pertama (pemilik modal) menyediakan seluruh modal sedangkan pihak pengelola dana bertindak selaku pengelola, keuntungan diantara mereka dibagi berdasarkan kesepakatan sedangkan kerugian ditanggung oleh pengelola modal, (Muhammad, 2009).

Mudharabah adalah akad kerja sama antara bank syariah sebagai penyedia dana $100 \%$ (shabibulal-mal) dengan nasabah atau pengusaha sebagai pengelola proyek (mudharib). Keuntungan proyek dibagi kepada kedua pihak sesuai dengan proporsi (nisbah) yang disepakati dalam perjanjian, (Purnamasari, dan Suswinarno, 2011).

Apabila usaha tersebut mengalami kegagalan, sehingga karena itu terjadi kerugian yang sampai mengakibatkan sebagian atau, bahkan, seluruh modal yang ditanamkan oleh shahib almal habis, maka yang menanggung kerugian keuanganhanya shabib al-mal sendiri, sedangkan mudharib sama sekali tidak menanggung atau tidak harus mengganti kerugian atas modal yang hilang, kecuali apabila kerugian tersebut terjadi sebagai akibat kecurangan yang dilakukan oleh mudharib (Sjahdeini,2007).

Bagi hasil adalah suatu sistem pengolahan dana dalam perekonomian Islam yakni pembagian hasil usaha antara pemilik modal (shabibul maal) dan pengelola (mudharib). Muhammad menjelaskan pelarangan riba dalam Islam adalah suatu penolakan terhadap timbulnya risiko finansial tambahan yang ditetapkan dalam transaksi uang atau modal maupun jual beli yang dibebankan kepada satu pihak saja sedangkan pihak yang lain dijamin keuntungannya. Hal ini mengindikasikan perbankan Syariah menganut sistem bagi hasil dalam proses kegiatannya dan mengharamkan bunga karena mengandung unsur riba.

Pembayaran imbalan bank syariah kepada pemilik dana dalam bentuk bagi hasil besarnya sangat tergantung dari pendapatan yang diperoleh sebagai mudharib atas pengelolaan dana Mudharabah tersebut. Apabila bank syariah memperoleh hasil usaha yang besar maka distribusi hasil usaha didasarkan pada jumlah yang besar, sebaliknya apabila bank syariah memperoleh hasil usaha yang kecil. Hal ini berbeda dengan bank konvensional, dimana pembayaran imbalan dalam bentuk bunga dibayarkan dengan jumlah tetap, tidak terpengaruh dengan pendapatan yang diterima bank konvensional. Dalam sistem bagi hasil terdapat prinsip-prinsip untuk menjalankan aktivitasnya yaitu :

a. Prinsip Keadilan dan Kehati-hatian tercermin dari penerapan imbalan atas dasar bagi hasil dan pengambilan margin keuntungan yang disepakati bersama antara bank dengan nasabah kemudian bank sebagai pengelola akan mengembangkan dana yang terkumpul dari nasabah untuk usaha-usaha yang baik secara profesional;

b. Prinsip Kesederajatan, dimana menempatkan nasabah penyimpan dana, nasabah pengguna dana, maupun bank pada kedudukan yang sama dan sederajat. Hal ini tercermin dalam hak, kewajiban, risiko, dan keuntungan yang berimbang antara nasabah penyimpan dana, nasabah pengguna dana, maupun bank;

c. Prinsip Ketentraman.Produk-produk Bank Syariah telah sesuai dengan prinsip dan kaidah Muamalah Islam, antara lain tidak adanya unsur riba serta penerapan zakat harta. Dengan demikian, nasabah akan merasakan ketentraman lahir maupun batin (Mutasowifin dalam Raihanah Daulay, 2010:5).

Distribusi pembagian hasil usaha bank syariah dengan nasabah penghimpunan dana hanya didasarkan pada akad Mudharabah, pembagian hasil usaha dilakukan bedasarkan pada nisbah yang disepakati ada awal akad. 
AL-MASHRAFIYAH: Jurnal Ekonomi, Keuangan, dan Perbankan Syariah Volume 2, Nomor 2, Oktober 2018

Tabel 2. Perbedaan Bunga dan Bagi Hasil

\begin{tabular}{|c|c|}
\hline Bunga & Bagi hasil \\
\hline $\begin{array}{l}\text { a. Penentuan bunga dibuat pada waktu } \\
\text { akad tanpa berpedoman pada untung } \\
\text { rugi }\end{array}$ & $\begin{array}{l}\text { Penentuan besarnya rasio bagi hasil dibuat } \\
\text { pada waktu akad dengan berpedoman pada } \\
\text { kemungkinan untung rugi }\end{array}$ \\
\hline $\begin{array}{l}\text { b. Besarnya persentase bedasarkan pada } \\
\text { jumlah uang (modal) yang dipinjamkan }\end{array}$ & $\begin{array}{l}\text { Besarnya rasio bagi hasil bedasarkan pada } \\
\text { jumlah keuntungan yang diperoleh }\end{array}$ \\
\hline $\begin{array}{l}\text { c. Pembayaran bunga tetap seperti yang } \\
\text { dijanjikan tanpa pertimbangan apakah } \\
\text { proyek yang dijalankan oleh pihak } \\
\text { nasabah untung atau rugi }\end{array}$ & $\begin{array}{l}\text { Bagi hasil tergantung pada keuntungan } \\
\text { proyek yang dijalankan, sekiranya itu tidak } \\
\text { mendapatkan keuntungan maka kerugian } \\
\text { akan ditanggung bersama oleh kedua pihak }\end{array}$ \\
\hline $\begin{array}{l}\text { d. Jumlah pembayaran bunga tidak } \\
\text { meningkat sekalipun jumlah } \\
\text { keuntungan berlipat }\end{array}$ & $\begin{array}{l}\text { Jumlah pembagian laba meningkat sesuai } \\
\text { dengan peningkatan jumlah pendapatan }\end{array}$ \\
\hline $\begin{array}{l}\text { e. Eksistensi bunga diragukan oleh } \\
\text { semua agama termasuk Islam }\end{array}$ & $\begin{array}{l}\text { Tidak ada yang meragukan keabsahan bagi } \\
\text { hasil }\end{array}$ \\
\hline
\end{tabular}

Sumber: (Antonio \& Karnaaen)

Dalam bagi hasil, penentuannya dalam bentuk persentase atau biasa disebut nisbah. Nisbah dalam buku Sri Nurhayati dan Wasilah berjudul Akuntansi Syariah di Indonesia, didefinisikan sebagai besaran yang digunakan untuk pembagian keuntungan. Nisbah mencerminkan imbalan yang berhak diterima oleh kedua pihak dan pemilik dana tidak boleh meminta pembagian keuntungan dengan menyatakan nilai nominal tertentu karena dapat menimbulkan riba (2009:117).

Nisbah harus diketahui jelas oleh kedua belah pihak. Jika dalam akad tidak dijelaskan masing-masing porsi maka pembagiannya menjadi 50\% dan 50\%. Hal hal yang berkaitan dengan bagi hasil sebagai berikut:

1. Persentase Nisbah keuntungan harus didasarkan dalam bentuk persentase antara kedua belah pihak, bukan dinyatakan dalam nilai nominal rupiah tertentu. Nisbah keuntungan itu misalnya 50:50 \%, 70:30\%, 60:40\% atau 55:45\%. Jadi nisbah keuntungan ditentukan berdasarkan kesepakatan, bukan berdasarkan porsi setoran modal.

2. Bagi Untung dan Bagi Rugi, Dalam kontrak ini, return dan timingcash flow kita tergantung kepada kinerja riilnya.Bila laba bisnisnya besar, kedua belah pihak mendapat bagian yang besar pula. Bila laba bisnisnya kecil, mereka mendapat bagian yang kecil juga. Filosofi ini hanya dapat berjalan jika nisbah laba di tentukan dalam bentuk persentase, bukan dalam bentuk nominal rupiah tertentu.

3. Jaminan Ketentuan pembagian kerugian bila kerugian yang terjadi hanya murni diakibatkan oleh resiko bisnis (business risk), bukan karena risiko karakter buruk mudharib (characterrisk). Bila kerugian terjadi karena karakter buruk, misalnya karena mudharib lalai dan atau melanggar persyaratan-persyaratan kontrak pembiayaan, maka Shabibul Maal tidak perlu menanggung kerugian seperti itu. Sedangkan untuk characterrisk, mudharib pada hakikatnya menjadi wakil dari Shabibul Maal dalam mengelola dana dengan seizin shabibul maal, sehingga wajib baginya berlaku amanah. Jika mudharib melakukan keteledoran, kelalaian, kecerobohan dalam merawat dan menjaga dana, yaitu melakukan pelanggaran, kesalahan, dan kelewatan dalam perilakunya yang tidak termasuk dalam bisnis pembiayaan yang disepakati, atau ia keluar dari ketentuan yang disepakati, mudharib tersebut harus menanggung kerugian pembiayaan sebesar bagian kelalaiannya sebagai sanksi dan tanggungjawabnya. Ia telah menimbulkan kerugian karena kelalaian dan perilaku zalim karena ia telah 
Ismawati. Mekanisme dan Masalah Pembiayaan Mudharabah...

memperlakukan harta orang lain yang dipercayakan kepadanya di luar ketentuan yang disepakati .Mudharib tidak pula berhak untuk menentukan sendiri mengambil bagian dari keuntungan tanpa kehadiran atau sepengetahuan Shabibul Maal sehingga Shabibul Maaldirugikan. Jelaslal ini konteksnya adalah Character Risk. Pihak Mudharib yang lalai atau menyalahi kontrak ini, maka shabibal-maal dibolehkan meminta jaminan tertentu kepada mudharib. Jaminan ini akan disita oleh Shabib Maaljika ternyata timbul kerugian karena mudharib melakukan kesalahan, yakni lalai dan ingkar janji.

4. Menentukan Besarnya Nisbah Keuntungan Besarnya nisbah ditentukan berdasarkan kesepakatan masing-masing pihak yang berkontrak. Jadi, angka besaran nisbah ini munculsebagai hasil tawar-menawar antara shabib maal dengan mudharib. Dengan demikian, angka nisbah ini bervariasi, bisa 50:50, 60:40, 70:30,80:20, bahkan 99:1. Namun para ahli fiqih sepakat bahwa nisbah 100:0 tidak diperbolehkan. Dalam prakteknya di perbankan modern, tawar menawar nisbah hanya terjadi pada deposan dengan jumlah besar karena memiliki daya tawar yang relatif tinggi (special nisbah). Sedangkan untuk deposan kecil tawar menawar tidak terjadi. Bank syariah hanya mencamtumkan nisbah yang ditawarkan, setelah itu deposan boleh setuju atau tidak. Bila tidak setuju, nasabah dipersilakan mencari bank syariah lain yang menawarkan nisbah yang lebih menarik (Adiwarman, 2013:206-209).

\section{METODE PENELITIAN}

Penelitian ini menggunakan metode penelitian Kualitatif, dengan pendekatan deskriptif. Walaupun berjenis penelitian deskripsi namun studi ini tidak hanya mendeskripsikan data kualitatif yang diperoleh, lebih dari itu data diinterpretasikan agar menjadi wacana dan konklusi dalam berpikir logis, praktis, dan teoritis. Penelitian kualitatif berdasar pada fenomena atau realitasosial yang terjadi. Penelitian kualitatif merupakan paradigma penelitian yang menekankan pada pemahaman mengenai masalah-masalah dalam kehidupan sosial berdasarkan kondisi realitas atau natural setting yang holistic, kompleks dan rinci.

Penelitian ini dilakukan dengan melihat dan mengeksplor tanggapan terkait dengan lambannya perkembangan pembiayaan Mudharabah di Bank Bank Panin Dubai Syariah, apa saja yg menjadi hambatan serta bagaimana penelitian ini dilakukan untuk bagaimana preferensi nasabah terhadapa pembiayaan Mudharabah di Bank Panin Dubai Makassar.

Pendekatan yang digunakan dalam penelitian ini adalah pendekatan deskriptif kualitatif. Data yang dikumpulkan pada pendekatan ini berupa kata-kata, gambar, dan bukan berupa angka-angka. Dengan demikian, laporan penelitian akan berisi kutipan-kutipan data untuk memberi gambaran penyajian laporan tersebut. Penelitian ini menggunakan dua jenis sumber data yaitu data primer dan data sekunder. Adapun metode pengumpulan data yang digunakan dalam penelitian ini diantaranya; observasi, wawancara mendalam, studi pustaka, dan dokumentasi.

Pengolahan data dilakukan setelah data diperoleh dari hasil wawancara, dokumentasi, dan observasi langkah-langkah yang dilakukan, yaitu, (Lawrence, 2013).

1. Peneliti memulai mengorganisasikan semua data yang telah dikumpulkan.

2. Membaca data secara keseluruhan dan membuat catatan pinggir mengenai data yang dianggap penting kemudian melakukan pengkodean data

3. Menemukan dan mengelompokkan pernyataan yang dirasakan oleh responden dengan melakukan horizonaliting yaitu setiap pernyataan yang tidak relevan dengan topik dan pertanyaan maupun pernyataan yang bersifat retitif atau tumpang tindih 
4. Reduksi data (data Reduction), memilah, memusatkan, dan menyederhanakan data yang diperoleh dari penelitian yang masih mentah yang muncul dari catatan-catatan tertulis dilapangan.

5. Penyajian data, yaitu dengan merangkai dan menyusun informasi dalam bentuk satu kesatuan, selektif dan dipahami.

Perumusan dalam simpulan, yakni dengan melakukan tinjauan ulang di lapangan untuk menguji kebenaran dan validitas makna yang muncul disana.Hasil yang diperoleh diinterpretasikan, kemudian disajikan secara naratif.

\section{HASIL DAN PEMBAHASAN}

\section{A. Mekanisme pembiayaan Mudharabah pada kantor cabang PT. Panin Bank Syariah Makassar}

Bank Panin Dubai Syariah sebagai sebuah lembaga keuangan syariah memiliki sistem operasional yang sudah tersusun secara sistematis. Dalam pembiayaan Mudharabah Bank Panin Dubai Syariah memiliki prosedur yang harus di patuhi oleh pegawai maupun calon nasabah. Sehingga dalam operasional pembiayaan Mudharabah pada Bank Panin Dubai Syariah dapat berjalan dengan baik. Pembiayaan Mudharabah merupakan pembiayaan yang disalurkan oleh Bank kepada Mudharib untuk kemudian hasil keuntungan pengelolaan di bagi hasilkan antara bank sebagai shahibul mal dengan nasabah sebagai mudharib sesuai dengan presentase (nisbah) bagi hasil yang telah ditetapkan. Pembiayaan Mudharabah pada Bank Panin Dubai Syariah terdiri atas dua. Pertama, Mudharabah Mutlaqah mekanisme yang dilalui mudharib diberikan kebebasan dalam mengelola dana Shabibul Mal (Sepanjang memenuhi syariat islam). Kedua, Mudharabah Muqayyadah dalam pengelolaannya Mudharib wajib mengelola dana sesuai keinginan Shaibibul Mal, misalnya kepada proyek/nasabah tertentu.

Produk pembiayaan Mudharabah pada Bank Panin Dubai Syariah berawal pada tahun 2014 hingga saat ini dengan jumlah nasabah sebanyak 4 UUS, diantaranya dari Badan Perkreditan Rakyat Syariah, Koperasi Syariah, Pegadaian Syariah, dan 1 Unit Usaha Syariah yang bekerja sama dengan pihak Bank dalam Pembiayaan Mudharabah tersebut, Sejauh ini pihak nasabah yang terikat hubungan kerja dangan pihak bank Badan Usaha yang berbasis syariah yang disetiap pengurus perusahaannya adalah masyarakat muslim. Menurut pihak Marketing Bank Panin Dubai Syariah salah satu alasan dalam mengambil keputusan nasabah yang hanya berbasis UUS, melihat resiko dari pembiayaan yang relatif tinggi dalam pemberian modal sehingga Pihak Bank menyeleksi ketat nasabah yang ingin mengajukan permohonan. Pengklasifikasian nasabah pembiayaan tersebut berdasarkan Surat Edaran OJK No.8/SEOJK.03/2015 tentang penilaian aset Bank Umum Syariah, Unit Usaha Syariah, didasarkan pada 3 pilar (Prospek Usaha, Kinerja Nasabah, Kemampuan Membayar).

Adapun prosedur pembiayaan Mudharabah. Nasabah mengajukan permohonan pembiayaan kepada bank disertai berkas dokumen yang diperlukan untuk pembuatan proposal pembiayaan.

1. Tahap Permohonan

Dalam Tahap Permohonan Mengisi formulir pengajuan yang sudah di sediakan oleh Bank Panin Dubai Syariah, sebagai bukti keseriusan mengajukan pembiayaan. Formulir ini menjadi arsip bank yang akan menjadi identitas calon nasabah. Dari form ini bank mendapatkan identitas lengkap dari calon nasabah yang akan mengajukan pinjaman. Calon nasabah mengajukan surat permohonan pembiayaan dengan cara mengisi form yang sudah disediakan oleh bank dengan melampirkan beberapa dokumen persyaratan.

Calon nasabah mempunyai tanggung jawab untuk memenuhi semua persyaratan yang di tentukan oleh Bank Panin Dubai Syariah. Yang mana persyaratan tersebut akan menjadi 
Ismawati. Mekanisme dan Masalah Pembiayaan Mudharabah...

bahan pertimbangan bagi pihak Bank Syariah apakah pembiayaan yang diajukan oleh nasabah bisa di realisasi atau tidak. Adapun persyaratan yang ditentukan oleh Bank Panin Dubai Syariah kepada pihak terkait yaitu Badan Usaha sebagai berikut :

a. Syarat-Syarat Dokumen Permohonan Pembiayaan

1) Foto copy akte pendirian badan usaha

2) Foto copy legalitas usaha sesuai dengan jenis bidang usaha

3) Dokumen pengurus perusahaan

4) Dokumen perijinan usaha

5) Laporan keuangan 2 tahun terakhir

6) Mutasi rekening bank 1 Tahun terakhir

7) Foto copy bukti pemilik jaminan

8) Dokumen lain yang dibutuhkan (sesuai tipe nasabah)

Dari informasi yang diberikan oleh salah seorang marketing pihak Bank Panin Dubai Syariah Bapak Bambang Sutomo menjelaskan bahwa persyaratan nasabah selain dari penyertaan dokumen dan berkas dalam pengajuan permohonan pihak bank juga melihat dari :

a. Operasional nasabah berlangsung minimal 2 tahun.

b. Cashflow nasabah berdasarkan laporan keuangan dalam kondisi positif

c. Usaha nasabah serta tujuan atas kebutuhan pembiayaan tidak bertentangan dengan prinsip syariah

d. Nasabah telah memiliki perijinan terkait dengan usaha yang dijalankan.

Peryataan tersebut menurut Bapak Bambang dikarenakan, usaha pembiayaan dalam bentuk penyertaan modal dianggap lebih besar risikonya terutama pada akad Mudharabah. Karena pada akad Mudharabah ini, pihak bank menyediakan 100 persen kebutuhan modal usaha sedang pihak pengusaha menyediakan jasa pengelolaan usaha. Sehingga dengan adanya penyertaan bahwa operasional badan usaha yang mengajukan telah berlangsung minimal 2 tahun memungkinkan bahwa badan usaha tersebut telah diakui dan mampu dalam mengelola perusahaan. Dalam permohonan tersebut badan usaha yang yang dijalankan juga tidak bertentangan dengan prinsip syariah.

Berdasarkan praktek yang diterapkan oleh pihak Bank Syariah sejalan dengan Teori yang dikemukakan oleh Imam al-Ghazali memandang bahwa suatu kemaslahatan harus sejalan dengan tujuan syara', sekalipun bertentangan dengan tujuan-tujuan manusia (Zuhdi, 2013). Pihak Bank Panin Dubai Syariah melihat atau merealisasikan permohonan kepada badan usaha yang hanya sesuai dengan prinsip syariah, meskipun pada kenyataanya banyak badan usaha yang memiliki operasional lebih dari dua tahun dengan laporan keungan yang cenderung positif namun tidak berdasarkan aspek syariah itu tidak dibenarkan oleh pihak Bank Panin Dubai Syariah. Oleh sebab itu, yang dijadikan patokan dalam mentukan kemaslahatan itu adalah kehendak dan tujuan syara, bukan kehendak dan tujuan manusia.

2. Setelah nasabah mengajukan permohonan pembiayaan kemudian diserahkan kepada AO. Surat permohonan dicatat pada admistrasi "permohonan pembiayaan".

3. Kemudian account officer menyerahkan surat permohonan berikut lampirankepada kepala KCP untuk memperoleh keputusan awal "disetujui untuk diproses atau tidak".

4. Jika surat permohonan disetujui maka marketing manajer menyerahkan surat permohonan kepada AO untuk di investigasi. Jika ternyata surat permohonan ditolak surat permohonan diserahkan kepada AO untuk dibuatkan surat penolakannya.

Melihat jumlah nasabah pada Bank Panin Dubai Syariah yang setiap tahunnya tidak mengalami perkembangan, kebanyakan dari setiap pemohon yang mengajukan tidak sedikit yang ditolak, Adapun penyabab penolakan antara lain :

a. Nasabah dianggap belum layak untuk diberikan fasilitas pembiayaan (tidak bankable)

b. Nasabah tidak memiliki dokumen lengkap atas perijinan usaha yang dijalankan 
AL-MASHRAFIYAH: Jurnal Ekonomi, Keuangan, dan Perbankan Syariah Volume 2, Nomor 2, Oktober 2018

c. Nasabah tidak dapat memberikan dokumen yang diminta olh pihak Bank

d. Peruntukan pembiayaan tidak sesuai dengan syariat Islam.

Menurut Bapak Bambang Sutomo menganai pengajuan dokumen permohonan mengatakan bahwa ketika terdapat syarat yang tidak dapat dipenuhi oleh nasabah maka permohonan atas pengajuan pembiayaan tidak dapat diproses lebih lanjut.

Pihak Bank Panin Dubai Syariah berusaha semampunya untuk memberikan pembiayaan sesuai dengan permintaan nasabah selama persyaratan yang diberikan mampu dipenuhi pihak nasabah, namun ketika kondisi berbalik Bank Panin Dubai Syariah Makassar tidak dapat memberikan pembiayaan, hal tersebut tetap akan dikomunikasikan dengan nasabah sesuai hasil keputusan komite pembiayaan atas pengajuan pembiayaan yang diusulkan.

5. Adapun kontrak pembiayaan Mudharabah yang diterapkan:

a. Kedua belah pihak yang akan bertransaksi (shahibul mal dan mudharib) harus saling memahami isi akad

b. Usaha yang dijalankan sesuai dengan prinsip syariah yaitu usaha yang halal

c. Di awal akad disepakati nisbah bagi hasil antara pemilik dengan pengelola dana

d. Pemilik dana tidak dapat ikut dalam manajemen usaha namun mempunyai hak untuk mengawasi.

6. Penentuan Bagi Hasil Pembiayaan Mudharabah

Dalam penentuan bagi hasil ada ketentuan yang harus disetujui oleh pihak Bank Panin Dubai Syariah dan nasabah, Yaitu :

a. Adanya kesepakatan antara pihak Bank (Sabibul Maal) dan nasabah (Mudharib) mengenai usaha yang akan dilakukan, dan jangka waktu.

b. Nisbah bagi hasil bedasarkan Revenue Sharing. Untuk memperjelas penghitungan bagi hasil pada pembiayaan

Dengan ilustrasi penghitungan bagi hasil Mudharabab: Bagi Hasil = Keuntungan $\mathrm{x}$ Nisbah sesuai kespakatan.

\section{B. Analisis Kendala Dan Hambatan Dalam Pelaksanaan Pembiayaan Mudharabah}

Pembiayaan Mudharabah pada Bank Panin Dubai Syariah Makassar memiliki portofolio lebih rendah dibandingkan dengan pembiayaan murabahah. Melihat bahwa nasabah Bank Panin Syariah pada pembiayaan Mudharabah saat ini di kota Makassar hanya memiliki 4 anggota nasabah. Realita tersebut menunjukkan bahwa dalam pembiayaan Mudharabah di Bank Panin Dubai Syariah terdapat beberapa kendala. Dari hasil observasi dan wawancara pegawai Bank Panin Dubai Syariah disimpulkan kendala kendalanya sebagai berikut:

1. Dari kebijakan Bank Panin Dubai Syariah yang menentukan nominal pembiayaan Mudharabah.

Adapun jumlah minimal pembiayaan diatur berdasarkan segmentasi nasabah. Dengan nominal terendah sebesar Rp. 100 juta dan nilai maksimal sebesar batas maksimum pemberian pembiayaan Bank Panin Dubai Syariah yang berada di kisaran Rp.250 Milyar. Melihat dari penetapan nominal pada pembiayaan tersebut, sehingga aspek pasar yang dicari lebih kepada kelas pengusaha dan lembaga keungan yang sudah berdiri dan cukup besar. Sementara masyarakat calon nasabah di daerah Kota Makassar tidak hanya dari kalangan pengusaha besar namun masih banyak pengusaha yang sifatnya UMKM.

Hal ini akan menyebabkan terhambatnya pembiayaan Mudharabab di Bank Panin Dubai Syariah. melihat hal ini marketing yang khususnya membidangi pada pembiayaan Mudharabah akan kesulitan mencari pangsa pasar karena adanya persaingan dengan bank-bank syariah maupun bank konvensional lain di Kota Makassar. 
Ismawati. Mekanisme dan Masalah Pembiayaan Mudharabah...

\section{Prosedur pembiayaan Mudharabah}

Dari prosedur pembiayaan Mudharabah di Bank Panin Dubai Syariah terdapat persyaratan yang harus di penuhi oleh nasabah yang diantaranya : (1) Foto copy akte pendirian / Anggaran dasar badan Usaha notariil (2) Foto copy legalitas usaha sesuai dengan jenis bidang usaha (5) Laporan keuangan (6) Rencana usaha kedepan. Melihat dari syarat-syarat tersebut akan sangat tidak mungkin bisa diperoleh oleh banyak masyarakat. Melihat jenis badan usaha masyarakat di wilayah Makassar tidak hanya berskala besar masih banyak diantaranya masih berupa usaha rumahan. Dengan demikian akan sangat tidak mungkin masyarakat bisa mendapatkan fasilitas pembiayaan Mudharabah.

\section{Persaingan dengan Bank Lain}

Banyaknya bank-bank di Kota Makassar dan Kabupaten, menjadikan persaingan antar bank tidak bisa dihindarkan. Baik bank konvensional maupun bank syariah sama-sama bersaing dalam mencari pasar. Bahkan persaingan antar satu bank beda KCP pun bisa terjadi. Hal ini menyebabkan pembiayaan Mudharabah di Bank Panin Dubai Syariah harus bisa bersaing dengan pembiayaan-penbiayaan lain.

Hal ini sejalan dengan peneltian terdahulu yang dilakukan oleh Budi Utomo yang dalam penelitian tersebut, melihat kendala dalam pembiayaan Mudharabah lebih kepada dari kebijakan Bank Panin Dubai Syariah yang menetapkan tarif tinggi pada pembiayaan Mudharabah yang membuat jangkauan dari pembiayaan Mudharabah menjadi pada kalangan pengusaha besar saja. Oleh sebab itu banyak masyarakat yang tidak tersentuh oleh pembiayaan Mudharabah.(Utomo, 2014).

Melihat adanya hambatan-hambatan yang terjadi dalam penerapan Bank Panin Dubai Syariah mampu diselesaikan dengan cara penyelesaian:

a) Bank Panin Dubai Syariah perlu membuat produk pembiayaan Mudharabah yang mana dari produk tersebut bisa dimanfaatkan oleh kalangan pengusaha mikro.Tidak harus pengusaha besar, tapi pengusaha kecil yang sedang merintis usaha pun bisa mendapatkan fasilitas pembiayaan Mudharabah. Pada dasarnya pembiayaan disalurkan untuk kemudian bisa dikembangkan oleh penerimanya. oleh karena itu Bank Panin Dubai Syariah harus bisa mengeluarkan pembiayaan Mudharabah dengan kapasitas nominal pembiayaan bisa terjangkau oleh masyarakat kecil.

b) Para Marketing Bank Panin Dubai Syariah harus bisa merangkul semua aspek pasar di masyarakat, sehingga terjalin rasa kepercayaan oleh masyarakat. Melakukan pengawasan usaha dengan baik, membina pengusaha baru yang sedang berdiri dan pemberian perhatian yang lebih kepada nasabahnya.

c) Persyaratan permohonan pembiayaan harus bisa lebih fleksible, artinya harus bisa menyesuaikan kondisi calon nasabah. Karena masih banyak pengusaha kecil di Makassar yang belum mempunyai laporan keuangan, perencanaan tahun berikutnya dll. Jadi dari segi persyaratan lebih difokuskan kepada jaminan dan karakter nasabah. Dengan demikian akan membantu pengusaha-pengusaha kecil untuk mendapatkan fasilitas pembiayaan Mudharabah.

Selain kendala tersebut dalam prakteknya Pihak Bank juga mendapati pembiayaan Mudharabah yang bermasalah. Beberapa penyebab pembiayaan bermalasah diantaranya :

a. Penurunan omset penjualan nasabah

b. Penyalahgunaan dana penyaluran pembiayaan (Penyaluran pembiayaan tidak sesuai dengan peruntukan awal)

c. Fource Majeure seperti bencana alam, dll.

Hal diatas dikemukakan oleh bapak Kamaruddin Kammisi selaku Branch Manager Bank Panin Dubai Syariah. Sejalan dengan pernyataan tersebut Menurut Syafi'I Anotonio dalam bukunya "Bank Syariah dari Teori ke Praktik", Risiko atau problem yang muncul yang 
terdapat pada Mudharabah, utamanya pada penerapan pembiayaan, relatif tinggi.Adapun yang dijelaskan dalam teori tersebut permasalahan yang terjadi biasanya : (1) Side Streaming yang mana nasabah menggunakan dana bukan seperti yang disebut dalam kontra, (2) Lalai dan kesalahan yang disengaja, (3) Penyebunyian keuntungan oleh nasabah bila nasabahnya tidak jujur. Melihat realita yang terjadi pada pembiayaan Mudharabah dalam perbankan syariah sejalan dengan teori yang ada, Sehingga tidak menutup kemungkinan bahwa setiap industri perbankan khusunya dalam produk pembiayaan memang dapat mengalami permasalahan karena risiko penerapan yang diterapkan relatif.

Hal ini juga sejalan dengan peneletian yang dilakukan oleh Ali Samsuri dengan judul Hambatan Kontrak Mudharabah Pada Perbankan Syari'ah bahwa adapun faktor yang menyebabkan adanya hambatan kurangnya kontrak Mudharabab dan permasalahan yang terjadi pada perbankan syariah diantaranya: Standar moral, ketidak efektifan model pembiayaan bagi hasil, berkaitan dengan para pengusaha, dari segi biaya, segi teknik, kurang menariknya system bagi hasil dalam bisnis dan permaslahan efesiensi, (Samsuri, 2015). Sehingga dalam prakteknya banyak kesalahan yang terjadi baik itu disengaja ataupun karena kelalaian dari pihak pengelola dana atau perusahaan.

Dalam berbagai permasalahan yang terjadi dalam perusahaan nasabah yang bekerja sama dengan pihak bank hal tersebut akan mempengaruhi kepada tingkat kolektibilitas, yang berdampak dengan pembayaran angsuran pembiayaanya. Berdasarkan peraturan Otoritas Jasa Keuangan (OJK) penggolongan atas kolllektibilitas nasabah terdiri dari beberapa faktor termasuk salah satunya yaitu ketetapan waktu pembayaran angsuran. Penggolongan Kollektibilitas nasabah antara lain :

1. Kolektibilitas 1 (lancar) pembayaran tepat waktu

2. Kolektibilitas 2 (dalam perhatian khusus) mengalami keterlabatan $1 \mathrm{~s} / \mathrm{d} 90$ hari

3. Kolektibilitas 3 (kurang lancar) mengalami keterlambata $91 \mathrm{~s} / \mathrm{d} 120$ hari

4. Kolektibilitas 4 (diragukan) mengalami keterlambatan $121 \mathrm{~s} / \mathrm{d} 180$ hari

5. Kolektibilitas 5 (macet) mengalami keterlambatan diatas 180 hari

Pembiayaan yang dikategorikan bermasalah apabila telah memasuki kategori kolektibilitas 3, 4, dan 5. Dimana pada kategori tersebut apabila usaha nasabah sudah tidak berjalan maka tidak ada bagi hasil yang dibayarkan ke bank. Apabila nasabah jatuh tempo dalam pembayaran, Ibu Khadijah salah satu staff dari analisis pembiayaan Mudharabah Bank Panin Dubai Syariah memberikan pernyataan bahwa atas jatuh tempo pembayaran angsuran nasabah, pihak bank telah melakukan reminder pembayaran sebelum tanggal jatuh tempo. Apabila kemudian nasabah terlambat melakukan pembayaran pihak bank akan melakukan kunjungan untuk melihat apakah terdapat problem atau masalah gangguan atas usaha yang dijalankan nasabah".

Hal tersebut dilakukan sebagai proses monitoring usaha sehingga pihak bank dapat memberikan bantuan atau bimbingan kepada nasabah. Selain dengan auditoring langkah yang dilalui oleh pihak Bank kembali dikemukakan oleh Ibu Khadijah bahwa, dengan mengidentifikasi kendala yang dihadapi oleh nasabah. Apabila Nasabah dianggap masih memiliki potensi usaha maka pihak bank akan mengupayakan langkah penyelamatan atas kondisi nasabah dengan pendampingan atau bantuan manajemen pihak bank. Dan apabila hal tersebut tidak memungkinkan maka ada beberapa cara penyelamatan lain diantaranya; (1) Rescheduling (penjadwalan ulang), (2) Reconditioning (pensyaratan ulang), (3) Restructuring (penataan ulang)".

Namun apabila nasabah dianggap tidak memiliki prospek usaha ke depan serta tidak memiliki itikad baik untuk penyelesaian permasalahan, maka bank akan menempuh langkah penyelesaian baik secara kekeluargaan maupun melalui pengaadilan agama. Biasanya 
Ismawati. Mekanisme dan Masalah Pembiayaan Mudharabah...

penyelesaian melalui pengadilan agama terjadi karena adanya masalah sengketa pembiayaan Mudharabah.

\section{Preferensi Nasabah Dalam Pembiayaan Mudharabah Pada Kantor Cabang PT. Panin Bank Syariah Makassar}

Pada tahap studi lapangan, peneliti dibantu dengan para surveyor melakukan dokumentasi wawancara yang berkaitan dengan persepsi atau preferensi nasabah terhadap pembiayaan Mudharabah. Adapun persepsi yang dimaksud antara lain: kepahaman nasabah terhadap bank syariah, mengenai pengetahuan nasabah tentang produk pembiayaan Mudharabah yaitu bagi hasil, bagaimana preferensi nasabah terhadap promosi pembiayaan serta pandangan nasabah terhadap praktek bank syari'ah baik penerapan maupun kualitas pelayanan jasanya dalam hal pembiayaan Mudharabah.

Tingkat pemahaman nasabah terhadap bank syariah adalah bervariasi, dari beberapa informan nasabah yang dimintai infomasi tentang promosi pembiayaan Mudharabah, sistem bagi hasil dan prakteknya pada perbankan syariah.

Menurut salah satu pihak nasabah pemilihan terhadap bank syariah dilakukan karena merasa lebih nyaman, aman dan tentram secara rokhani. Hal ini disebabkan antara lain: karena dapat terhindar dari bunga bank, karena lebih menguntungkan, dan lebih sesuai dengan syariah berdasarkan pembagian keuntungan bagi hasil. Namun tidak sedikit pula Ketidakpahaman nasabah mengenai produk pembiayaan Mudharabah dikarenakan kurangnya promosi. Pemahaman nasabah terhadap produk pembiayaan Mudharabah masih sangat rendah. Nasabah mengenal nama produk pembiayaan Mudharabah namun tidak mengetahui sistem yang dijalankan berdasarkan akad-akad yang ada tidak dipahami secara menyeluruh dan jelas.

Namun berdasarkan hasil analisa data primer dengan metode wawancara, preferensinasabah yang mengajukan pembiayaan Mudharabah syari'ah dilatarbelakangi oleh berbagai-macam alasan. Diantaranya faktor-faktor yang mempengaruhi nasabah dalam mengambil keputusan pembiayaan Mudharabah antara lain: keuntungan, keimanan atau ketauhidan, kenyamanan dalam kualitas pelayanan, nisbah yang rendah, serta faktor kebermanfaatan

\section{PENUTUP}

\section{a. Simpulan}

Berdasarkan penelitian yang dilakukan oleh penulis, maka penulis dapat menyimpulkan sebagai berikut :

1. Prosedur pembiayaan Mudharabah di Bank Panin Dubai Syariah Makassar di mulai dari permohonan pembiayaan nasabah dengan cara mengisi formulir atau aplikasi beserta menyertakan persyaratan awal.Pengisian aplikasi tersebut didampingi dan dianalisa oleh AO. Berdasarkan hasil analisa yang dilakukan oleh AO akan dilakukan komite yang mana tahap ini berfungsi untuk memutuskan apakah pembiayaan akan di ACC atau tidak. Pihak Bank Panin Dubai Syariah berusaha semampunya untuk memberikan pembiayaan sesuai dengan permintaan nasabah selama persyaratan yang diberikan mampu dipenuhi pihak nasabah dan sesuai dengan aspek syariah, namun ketika kondisi berbalik Bank Panin Dubai Syariah Makassar tidak dapat memberikan pembiayaan, hal tersebut tetap akan dikomunikasikan dengan nasabah sesuai hasil keputusan komite pembiayaan atas pengajuan pembiayaan yang diusulkan, AO juga melakukan monitoring terhadap nasabah. Monitoring tersebut berupa pengawasan dan pembinaan terhadap nasabah dalam melakukan angsuran hingga pelunasan.terhadap nasabah dalam melakukan angsuran hingga pelunasan. 
2. Kendala pembiayaan Mudharabah lebih kepada dari kebijakan Bank Panin Dubai Syariah Makassar yang menetapkan tarif tinggi pada pembiayaan Mudharabah yang membuat jangkauan dari pembiayaan Mudharabah menjadi pada kalangan pengusaha besar saja. Oleh sebab itu banyak masyarakat yang tidak tersentuh oleh pembiayaan Mudharabah. Prosedur yang ditentukan oleh Bank Panin Dubai Syariah Makassar akan menyulitkan nasabah untuk melakukan pengajuan nasabah yang baru akan memulai kegiatan usahannya. Karena para pengusaha baru atau UMKM tidak bisa memenuhi persyaratan persyaratan yang ditetapkan dalam prosedur pembiayaan. Jugaadanya aturan yang ketat dari OJK bahwa hanya Unit usaha syariah yang boleh diberikan pembiayaan.

3. Tingkat pemahaman nasabah terhadap bank syari'ah bervariasi, dari beberapa informan nasabah yang dimintai infomasi tentang promosi pembiayaan Mudharabah, sistem bagi hasil pembiayaan Mudharabah dan prakteknya pada perbankan syariah. Masih sangat minim hal ini disebabkan kurangnya promosi baik tentang produk maupun sistem yang berlaku. Akan tetapi berdasarkan hasil analisa data wawancara, preferensi nasabah yang mengajukan pembiayaan Mudharabah syari'ah dilatarbelakangi oleh berbagai-macam alasan. diantaranya faktor-faktor yang mempengaruhi nasabah dalam mengambil keputusan pembiayaan Mudharabah antara lain: keuntungan, keimanan atau ketauhidan, kenyamanan dalam kualitas pelayanan, nisbah yang rendah, serta faktor kebermanfaatan

\section{b. Saran}

Berdasarkan analisa dan kesimpulan tersebut maka penulis memberikan saran-saran sebagai bahan pertimbangan untuk mengembangkan dan memajukan Bank Panin Dubai Syariah.

1. Prosedur yang diterapkan sudah memenuhi tingkat keamanan bagi bank, sehinggan mampu meminimalisir resiko. Maka dari itu diharapkan Bank Panin Dubai Syariah mampu terus menjaga dan menerapkan prosedur tersebut.

2. Persyaratan persyaratan yang ditetapkan harus mampu dijangkau oleh pengusaha kecil agar mampu mendapatkan fasilitas pembiayaan Mudharabah.

3. Bank Panin Dubai Syariah membuat kebijakan yang mana pembiayaan Mudharabah menyediakan modal murah, artinya bisa di bawah 100 juta.

4. Bank Panin Dubai Syariah harus mampu mengembangkan produk yang dapat mencakup semua kebutuhan masyarakat.

\section{DAFTAR PUSTAKA}

Abdul Ghofur Ansori. (2007). Perbankan Syariah di Indonesia. Yogyakarta: UGM Press Ali Hasan, (2010), Marketing Bank Syariah, Bogor: Ghalia Indonesia

Ali Samsuri, (2015). Hambatan Kontrak Mudharabah Pada Perbankan Syariah, Jakarta.

Amiruddin, K., (2017). Konseptualisasi Ekonomi Dan Keuangan Syariah. Al-Mashrafiyah (Jurnal Ekonomi, Kenangan dan Perbankan Syariab), 1(1).

Antonio Syafi'i, (2001), Bank Syariah dan praktek, Jakarta :Gema Insani

Arifin, Zainal. (2000). Memahami Bank Syariah. Jakarta: PT. Alvabet

Bambang, Supomo, Nur, Indriantoro.(2013)Metodologi Penelitian Bisnis Untuk Akuntansi dan Manajemen.Yogyakarta: BPFE. 
Ismawati. Mekanisme dan Masalah Pembiayaan Mudharabah...

Bungin, Burhan. (2013)Analisis Data Penelitian Kualitatif, Pemahaman Filosofis dan Metodologis ke Arah Penguasaan Model Aplikasi. Jakarta: PT. Raja Grafindo Persada.

Creswell W John. (2013)ResearchDesign.Pendekatan Metode Kualitatif, kuantitatif, dan campuran. Edisi 4

Darwis, D., (2018). Minat Masyarakat Kota Watampone Untuk Menggunakan Jasa Perbankan Syariah. Al-Mashrafiyah (Jurnal Ekonomi, Kenangan dan Perbankan Syariab), 1(2).

Herlin, H., (2018). Penerapan Akuntansi Deposito Amanah Berdasarkan Prinsip Bagi Hasil Mudharabah. Al-Mashrafiyah (Jurnal Ekonomi, Kenangan dan Perbankan Syariah), 1(2).

Himpunan Fatwa Dewan Syari'ah Nasional No.07/DSN-MUI/IV/2000 tentang Pembiayaan Mudharabah (Qiradh), hlm. 40.

Irma devita Purnamasari, Suswinarno, Akad Syariah, (Bandung : Kaifa, 2011), Cet. ke-1, h. 80

Isnaini dan Utary Maharany Barus (2015), Pelaksanaan Akad Pembiayaan Mudharabah di Bank Sumut Syariah Kota Medan, Skripsi S1, Medan, Universitas Medan Area dan Universitas Sumatera Utara.

Iqbal, Zamir \& Greuning, Hennie Van. (2011). Risk Analisis For Islamic Banks. Jakarta: Salemba Empat

Karim, Adiwarman A, (2013), Bank Islam: Analisis Fiqih dan Kenangan, Jakarta: PT. Raja. Grafindo Persada

Kementrian Agama RI. (2012). Al-Qur'an dan Terjemanhannya, Direktorat Jenderal Bimbingan Masyarakat Islam, Jakarta: PT. Sinergi Pustaka Indonesia

Laporan Perkembangan Perbankan Syariah (2015). Otoritas Jasa Keuangan. Jakarta

Neuman, W. Lawrence. (2013), Metodologi Penelitian Sosial: Pendekatan Kualitatif dan Kuantitatif. Eds.7. Penerjemah: Edina T. Sofia. Jakarta: PT. Indeks.

Pindah Bayu. (2014). Faktor-faktor yang mempengarubi keputusan mudharib dalam mengambil pembiayan Mudharabah pada lembaga keuangan syariah.Skirpsi UIN Sunan Kali Jaga. Yogyakarta.

Rum, M., 2017. Risk Control Of Contingency Transaction In Profit Sharing System. AlMashrafiyah (Jurnal Ekonomi, Keuangan dan Perbankan Syariab), 1(1).

Samsuri, Ali (2015), Hambatan Kontrak Mudharabab Pada Perbankan Syari'ah, Jakarta

Utomo, Budi. (2014), Analisis Pembiayaan Mudharabah pada Bank Syariah Kantor Cabang Pembantu Banyumanik, Skripsi Sekolah Tinggi Agama Islam Negeri (STAIN) Salatiga.

Sutan Remy Sjahdeini, Perbankan Islam dan Kedudukannya Dalam Tata Hukum Perbankan Indonesia,(Jakarta: Pustaka Utama Grafiti, 2007), Cet. ke-III, h. 27

Muhammad Harfin Zuhdi, (2013). "Formulasi Teori Maslahah Dalam Paradigma Pemikiran Hukum Islam Kontemporer", Istinbath12, No.1. (Desember 2013), b.291

Budi Utomo, (2014). Analisis Pembiayaan Mudharabah pada Bank Syariah Kantor Cabang Pembantu Banyumanik. Skripsi Sekolah Tinggi Agama Islam Negeri (STAIN) Salatiga. 